\title{
Retraction Note to: Carpal tunnel syndrome in patients who are receiving long-term renal hemodialysis
}

\author{
Hamid Namazi ${ }^{1,2} \cdot$ Zahra Majd $^{1}$
}

Published online: 3 May 2015

(c) Springer-Verlag Berlin Heidelberg 2015

\section{Retraction to: Arch Orthop Trauma Surg (2007) 127:725-728 \\ DOI 10.1007/s00402-007-0350-7}

The article has been retracted by the Co-Editor because it has been found that the authors have duplicated substantial parts and have manipulated some original data from the following article: Association between Carpel Tunnel Syndrome and Arteriovenous Fistula in Hemodialysis Patients, Jamal Gousheh, Afshin Iranpour, Plastic and Reconstructive Surgery, Vol. 116, No. 2, pages 508-513, DOI:10.1097/01.prs.0000172893.59458.8a, without acknowledging the source.

The online version of the original article can be found under doi:10.1007/s00402-007-0350-7.

\section{Hamid Namazi}

Namazih@sums.ac.ir

1 Department of Orthopaedic Surgery, Shiraz University of Medical Sciences, Shiraz, Iran

2 Chamran Highway, Chamran Hospital, Box 71334, Shiraz, Iran 